\title{
Value Based Thematics Learning
}

\author{
Tahmid Sabri \\ Pendidikan Dasar/PGSD FKIP UNTAN, Pontianak, Indonesia \\ E-mail: tahmidsabripgsd@gmail.com
}

\begin{abstract}
Today, the ever-changing curriculum development in accordance with the power holder and the authority in issuing the policy has revamped the previous curriculum (Curriculum Unit of Education Unit) into the Curriculum 2013. This, of course, has an enormous impact on the implementation of life values in every aspect.
\end{abstract}

Keywords: Learning; Thematic; Value

\section{INTRODUCTION}

The role of teachers in an effort to improve the quality of education is very large because teachers are the front spearhead in the process of learning in the classroom. Knowledge, attitudes, and skills of teachers to be a factor supporting the success of students in learning. Teachers as educators should be able to help students grow and develop to be wise, and prospective (Maslow in Ertikanto, 1998: 2). Thus, teachers are required not only to convey cognitive aspects but also to integrate knowledge, attitudes, and skills with each other (Kosasih, 1996: 32) through thematic learning. Knowledge is not only owned but also can be used as a tool to behave nuanced good value.

Value as the identity of the price that becomes normative for a person in doing something. The psychological way of something that is done is actually a radiance that comes from the Divine values, God the Most True (Al-Gazali, 2007: 1034). Values education needs to be invested in children, including elementary students through the application of thematic value-themed nuances. This means that teachers do not just implement thematic lessons, but the element of value is an important thing of concern. In the Qur'an is ordered, the substance is: "O ye who believe, guard yourselves, your family from the torment of hellfire" (Q.S. 66 Attahrim: 6). On this basis, the cognitive, affective and psychomotor aspects must be integrated into a unity in the learning in a thematic way.

Thematic is a learning approach that blends the conceptual concepts of some subjects that focus on the central theme. Through thematic, student activities, student creativity, collaboration in learning, independence, self-confidence and student responsibilities can be greatly forged. According to the Curriculum 2013, thematic learning is conducted from class I to class VI. There are 3 (three) important things that need to be developed in Curriculum 2013 are: (1) attitude (attitude); (2) skilling (skill); and (3) knowledge. The thematic learning is applied using a scientific approach that is: observing, asking, reasoning, trying, and forming.

The development of the child as a whole is interrelated, in which the child sees the real world in a holistic, integrated, and interconnected relationship between developments with each other (Kartadinata, 1997: 18). Teachers should pay attention to the trends that are being experienced by the child, such as: moving from concrete things, looking at something learned as a whole, integrated and manipulative that is the process of tinkering with concrete objects with his own hands while building valuable schemata in repertoire of students' knowledge (Srini, 1997: 36). However, seen from the fact that occurred in the elementary school, so far still show a gap between hope and reality, such as: (1). The occurrence of rigorous subject-learning, especially in the high classes; (2). Learning only emphasizes the mastery of concepts regardless of other spheres; and (3). Teachers tend to pursue targets, especially the cognitive aspects of less attention to aspects of attitude. Asy'ari's study (1997: 4) suggests (a) a follow-up study of integrated learning for other central themes in different classes and schools. (b) Integrated learning can be used as a variation of learning in 
primary school. The results of Tahmid's (2013: 226), "Internalization of values on students needs to be invested through value-based learning". Various values will be personal in students, such as discipline, diligence, responsibility, self-confidence, independence and martial arts.

In addition, it is necessary to instill the value of rural monotheism to the Creator of Allah SWT by inculcating the values of proof of his greatness and habits ubudiyah, such as: devoted to parents, prayer, reading Al-Qur'an dhikr, reading sholawat and do other good deeds. It makes students aware, active learning so as to obtain optimal learning outcomes. The cultivation of the values of the tauhidan and ubudiyah is the key to the success of students in learning (Tahmid, 2011: 40). Experts suggest that the importance of integrated learning is applied in every elementary school in Indonesia, but the realities in the field have not been well realized (Poedjiadi in Ash'ari, 1997: 5), the more thematic lessons of understanding, and the teacher's skills on integrated learning are lacking, including value-based thematic learning (Joni, 1997: 10).

\section{THEMATIC}

Thematic is an integrated learning approach of webbing model that combines three or more subjects by prioritizing the concepts, skills, or attitudes of each subject that depart from the central theme (Fogarty 1991: 71 ). Such learning can psychologically provide meaningful experiences for students because in their learning students will understand the essential concepts that will be learned through direct experiences, and relate them to other concepts they previously understood. The element of seeing, the element of hearing, and the element of doing is an essential part of unified learning, I see, I forget, I hear, I remember, I do and I understand. The learning is student-centered. Learning activities are more emphasis on students. Thematic learning can provide considerable opportunities for improving the learning achievement of students in a manner. For that scientific approach should be developed in thematic learning, because it can serve as a locomotor for students in learning. Observation, questioning, reasoning, application, and communication as a driving genre. Physical, mental and emotional elements are mutual reflecting which in the end there is activity, enthusiasm, and creativity in learning with diligence and independence (Sabri, Q 2016).

The various scientific activities are more intractable if supported by inquiry, based on the students' wishes themselves without more involvement of the teacher in finding a problem, the teacher is only limited to facilitator and motivator (Sabri, T, 2015). From here the emergence of values of sincerity, values of independence, and values of tranquility and some other divine values. Divine values are Islamic values that can give birth to the noble character (Sabri, T.2017).

Judging from the development of children (students), as proposed by the PGSD Development Team (1997: 2) that the development of elementary school children holistic (comprehensive), integrated and mutually interconnected aspects of development with one another. Kartadinata and Dantes (1997: 20) say that "the learning process and teaching materials must be integrated and related to the process of child development" the development is psychologically related to intellectual intelligence (IQ), emotional intelligence (EQ), and spiritual intelligence (SQ). through thematic, the three things (IQ, SQ, and EQ) can be developed to the students so that they will become cadres of a nation that is intelligent, creative, high dedication, and noble. Value-value learning can be used as an anticipation or a filter of negatives, especially for the Indonesian people affected by various multidimensional crises, such as economic crisis, moral crisis, moral crisis, and religious crisis (Wirnata, 2010: 1). Thematic is an approach that can generate activity, and creativity of students in learning. Students are called to do good, diligent, disciplined, confident, full of responsibility, tolerant, honest and respectful of others.

This thematic approach is appropriately developed in elementary schools, as it allows students to understand a phenomenon from all aspects of life, students can create a balance between intellectual activity with experience and the environment (Aswin, 1996: 43). Thematic learning needs to be supported by the Contextual Teaching Learning (CTL) approach or other approaches that can link concepts taught to realworld situations and can make the connection between knowledge and its application in real life (Blanchard, 2001). The Washington State Consortium for Contextual Teaching Learning (2001) identifies CTL's key elements of inquiring, constructivist, authentic judgment, reflection, and modeling. Thematic learning not only provides students with added value in learning but also for teachers (Peter, 1995: 639).

Thematic learning is applied through three stages: the planning stage, the implementation stage, and the culmination stage. The planning stage consists of: (1). General planning stages: (a) examine the curriculum of Grade I, II and III SD classes (KTSP); (b) determine the central theme, but according to the Curriculum 2013 themes and sub-themes are available in teacher books and student books; (c) to inventory the learning program in each related subject; (d) to prepare a 
schedule of activities and the determination of time allocation; (2) special planning stages: (a) create a network of concepts; (b) the allocation of time; (c) determine the scope of competency standards in the curriculum of 2013 the term SK (Competency Standards) is replaced by KI (Core Competencies, ie $\mathrm{KI} 1, \mathrm{KI} 2, \mathrm{KI} 3$, and $\mathrm{KI} 4 . \mathrm{KI} 1$ contains religious (religious values) KI2 contains social KI3 (d) to formulate learning objectives, (e) plan learning activities (learning scenarios including LKS), (f) establish learning tools and media, (g) plan evaluation and feedback; ) Descriptions of concepts from several related subjects; (4) make material details; (5) the time stipulation used in accordance with the curriculum requirements; (6) determination of instructional media, and (7) skill and attitude aspects to be developed. Learning structure consists of: (1) preliminary activity: salutation, class management, brainstorming / apperception, objective information and activity info to be conducted in learning; (2) Core activities, consisting of exploration, elaboration and confirmation activities; (3) Closing activities consisting of evaluation of the process and evaluation of results, ending in prayer. Other important things are: selection of approaches and methods; inventory of related concepts; use of media; the patterns of interaction between teachers and students should vary (teacher-student, studentteacher, and student) through exploration, elaboration, and confirmation activities (Permen Diknas 2007 No. 41). All of these components must be of nuanced value, both in the lesson planning and in the application during school learning.

\section{VALUE}

Value is the price given by a person or group of people to something (material, immaterial, personal, and conditional) or the price brought by the identity of something, for example, the price carried by the identity of the person, among others materially such as ancient objects, personally, among others, the Prophet / Prophet, conditional, such as winter season must be snowy and cold, sophisticated science and technology era will be easy and delicious (Djahiri, 1996: 17). In other words, that value is a belief that can color the behavior of the individual that aims to obtain peace of mind (istiqama), and used as a principle or standard in life (Sauri, 2008: 28).

Mulyana (2004: 32) asserted there are six reference values that are often used as benchmarks by humans in life, namely: (1) theoretical value; (2) economic value; (3) aesthetic value; (4) social value; (5) political value; and (6) religious values (Mulyana, 2004: 33). From the context of education, the internalization of values through thematic learning aims to form a complete human personality (Sauri and Firmansyah, 2010: 15). In other words, that goal is expected to be used to achieve insan kamil, which implicates the behavior of students in everyday life. These values are classified into three types, namely: (1) the value of beauty (aesthetic philosophy); (2) the value of truth (epistemological philosophy); and (3) virtue value (ethical philosophy), (Suhartono, 2008: 137). Thus it can be underlined that what is meant here is the normative standard that can be used as a reference and belief in determining the choice of alternative action in accordance with the norms that apply as a standard of action or attitude that determines who we are, how we live and how we act and act. Individual students are actively able to develop their potential to have spiritual power, self-control, personality, intelligence, noble character and skills needed of him, society, nation, and state (Alwasilah, 2009: 45). Ghazali (Ali Khan, 2005: 126) unconsciously he did not float any personal philosophy. However, he introduces the creative heart-words in man with his faith that helps him develop the possibilities of unlimited growth and freedom, the growth of moral, spiritual and intellectual potentials; in other words, his brain is intelligent, receptive to his heart, and skillful of his hands, so that a whole person is formed and gives birth to good manners as a good man called morals (Sauri, 2008); morals to self, morals to the family, morals to the surrounding environment, including morals to the environment of society, morals in worship, morals in the association, and morals towards Allah SWT. From the point of view of philosophy, values are grouped into three, namely (a) the value of beauty (aesthetic philosophy): (b) the value of truth (epistemological philosophy); and (c) Goodness value (ethical philosophy), (Suhartono, 2008: 137). Of these three values are grouped again into six classifications of values, namely: (1) theoretical value; (2) economic value; (3) aesthetic value; (4) social value; (5) political value; and (6) religious values (Mulyana, 2004). The value of religion is the value of camels that become the guidelines of human life.

The value of religion is, in essence, actually this value is the value that has the most fundamental truth base compared with other values. The value of religion comes from the highest truth that comes from God Almighty, Allah SWT. The scope of this value is broader and more universal that can bring mankind to the right path, to the path that is received from Allah Almighty, the salvation of the world and the hereafter. To achieve that expectation there is a need for harmony of all elements of life, between the will of man with the command of God, between words and actions or between faith and deeds, which gives birth to a noble character. 
According to the Curriculum 2013 as already expressed by Sabri, $\mathrm{T}$ in his article entitled "Practical Ways Internalization Thematic by Students in Learning Through Peer Teaching in PGSD FKIP at Tanjungpura University" (2017). The elements of attitude, knowledge (knowledge), and skilling (skills) are integrated in a unity, any concept that is taught to the students, the three elements must be able to give a practical reflection on each student, for example asking students to write a sentence simple in grade 3 elementary school students, "neatness, beauty, and cleanliness in writing", "attitude", "writing", "skill", and "simple sentence" are "knowledge". Accordingly in Thematic Learning, which consists of at least three Subjects that are in the same semester. Gradually when this is always conditioned in learning, psychologically must have a positive impact on each individual student toward a commendable behavior. This is what it says that Thematic Learning is value-based. That is why the Thematic Learning that is being treated by the Government of Indonesia is a precise and effective system to bring the nation's children towards the true Pancasila.

Actually the main target to be achieved in learning refers to the pillars of education Learning to know / knowledge satisfaction; Learning to do / skill acquisition; Learning to be / self-development; and Learning to live together / learning for the community in other words that the knowledge developed in the learning is not only the aspect of knowledge, skills, and just the value aspect, but other aspect also needs to be developed even as supporting aspects such as social aspects (Sabri, T. 2012).

\section{CONCLUSIONS}

From some of the above the following conclusions can be drawn:

- Valuable thematic learning needs to be implemented in elementary schools that have implications for students to actualize themselves in learning, such as learning, creative, independent, diligent, considerate, disciplined, responsible, democratic, and noble.

- Implementation in learning begins from making the design to the application.

- Thematic learning is a national program developed through education and learning in schools using an integrative 2013 Curriculum between attitudes, skills, and knowledge in line with the guidance of Law no. 20 of 2003 on National Education System.

- Thematic learning is an application of four teacher competencies: pedagogic, personality, professional, and social and the development of four pillars of education: learning to know, learning to do, learning to be, learning to live together.

- Valuable thematic learning can provide opportunities for teachers to develop PAIKEM in teaching (Active, Innovative, Creative, and Joyful Learning).

\section{REFERENCES}

Aswin, H.F. 1996. Psikologi Perkembangan Anak. Jakarta: Depdikbud.

Asy'ari, M. 1997. Pembelajaran Terpadu Antar Bidang Studi Sebagai Variasi Pengajaran di SD dengan Tema Sentral Bidang IPA. (Tesis). Bandung: PPS UPI Bandung.

Blanchard, A. 2001. Contextual Teaching and Learning/Jurnal Pendidikan Dasar, Vol. 7, No. 1, 2006: 50-60.

Depdikbud. 1995. Kurikulum Pendidikan Dasar/ GBPP, Kelas V Sekolah Dasar Tahun 1994. Jakarta: Dirjen DIKTI.

Diknas, 2006. Kurikulum Tingkat Satuan Pendidikan/ KTSP SD. Jakarta: Diknas.

Ertikanto, C. 1998. Pembelajaran Terpadu Model Integrated (Makalah). Bandung: PPS UPI Bandung.

Fogarty, R. 1991. How To Integrated The Curricula. Skylight Publishing, Inc. Palatine, Illinois.

Hopkins, D. 1993. A Teacher's Guide to Classroom Research. Second Edition Buckingham, Philadelphia: Open University Press.

Gazali, I. (2007). Ihya Ulumiddin/ Terjemahan Oleh Yakub, Ismail. Cetakan keenam. Jilid I. Singapura: Pustaka Nasional PTEKTD.

Joni, T.R. 1997. Pembelajaran Terpadu. Naskah untuk Pelatihan Guru Pamong SD, BP3GSD, DIKTI di Yogyakarta, Tanggal 4-16 Agustus 1997.

Kartadinata, S. Dan Dantes, 1997. LandasanLandasan Pendidikan Sekolah Dasar. Jakarta: Depdikbud.

Kemdikbud. 2013. Kurikulum Tahun 2013 Untuk Sekolah Dasar. Jakarta: Kemdikbud.

Djahiri, K.A.. 1996. Strategi Pengajaran Afektif Nilai Moral VCT dan Games dalam VCT. Bandung:UPI.

Muhadjir, N. 1996. Pedoman Pelaksanaan Penelitian Pendidikan Kelas, Bagian Keempat: Analisis dan Refleksi. Yogyakarta: Dirjen DIKTI.

Mulyana, R. 2004. Mengartikulasikan Pendidikan Nilai. Cetakan Pertama. Bandung: Alfabeta.

Peter, T. S.K dan Hopkins. 1995. A Thematic Approach: Theory and Practice at the Aleknagik School. Phi Delta Kappan. 76(8).633-636. 
Qur'an. Terjemahan Departemen Agama Republik Indonesia.

Sabri, T. (2012). Memupuk Kemandirian Sebagai Strategi Pengembangan Kepribadian Individu Siswa Dalam Belajar. Jurnal Pendidikan Sosiologi dan Humaniora, 1(1).

Sabri, T. (2015). Peningkatan Aktivitas Peserta didik Menggunakan Metode Inquirydi Kelas IV SDNegeri 13 Muara Pawan. Jurnal Pendidikan dan Pembelajaran, 4(1).

Sabri, T. (2016). Implimentasi Pendekatan Saintifikdalam Pembelajaran Tematik Kelas III SD Negeri 13 Pontianak Barat. Jurnal Pendidikan dan Pembelajaran, 5(3).

Sabri, T. (2017). Practical Ways Internalization Tematik by Students in Learning Through Peer Teaching in PGSD FKIP at Tanjungpura University. JETL (Journal Of Education, Teaching, and Learning), 2(1), 138-142.

Sauri, 2008.Hasil Rangkuman Matrikulasi Tentang Implikasi Nilai Pada Seorang Individu Tahun 2008 Program Doktor PU/Nilai. Bandung: UPI.
Sauri, S dan Firmansyah, H. 2010. Meretas Pendidikan Nilai. Bandung: CV Arifino Raya.

Srini., M.I. 1997. Pendidikan Ilmu Pengetahuan Alam. Jakarta. BP3GSD: Deirektorat Jenderal Pendidikan Tinggi (DIKTI).

Suhartono, S. 2008. Filsafat Pendidikan. Cetakan ketiga. Yogyakarta: Ar-Ruzz Media.

Suyanto. 1997. Pedoman Penelitian Tindakan Kelas. Bagian Kesatu. Yogyakarta: Direktorat Jenderal Pendidikan Tinggi (DIKTI).

Tahmid. 2013. Internalisasi Nilai-Nilai Kemandirian Siswa Dalam Pembelajaran IPA di SD (Disertasi). Bandung:UPI. 2011. Ketenangan Hati Dari Sudut Pandang Tauhid Menjadi Kunci Sukses Siswa Dalam Belajar. Jurnal Edisi April 2011. Pontianak: FKIP Untan.

Tim Pengembang PGSD. 1997. Pembelajaran Terpadu D-II PGSD dan S2 Pendidikan Dsaar. Jakarta: Direktorat Jenderal Pendidikan Tinggi (DIKTI).

Undang-undang Republik Indonesia No. 20 Tahun 2003 Tentang Sisdiknas (Online): www.hukumonline.com

Wiranata, U.S. 2010. Implementasi Kebijakan Nasional Tentang Pembangunan Karakter Bangsa. (Online): www.hukumonline.com. 